\title{
PENGARUH UPAH DAN PENDIDIKAN TERHADAP PRODUKTIVITAS TENAGA KERJA DI PROVINSI JAMBI
}

\author{
Prima Audia Daniel \\ Dosen Tetap Universitas Muhammadiyah Jambi \\ primaaudia@ymail.com
}

\section{Ringkasan}

Penelitian ini dilator belakangi oleh rendahnya produktivitas tenaga kerja di Provinsi Jambi, dengan tujuan mengetahui dan menganalisis berapa besar pengaruh upah dan tingkat pendidikan terhadap produktivitas tenaga kerja yang ada di provinsi Jambi. Dalam penelitian ini menggunakan metode deskriptif kuaantitatif dengan menggunakan data sekunder, dan menggunakan model regresi berganda. Hasil penelitian menunjukkan bahwa baik secara parsial dan simultan upah dan pendidikan berpengaruh positif dan tidak signifikan terhadap produktivitas tenaga kerja di provinsi Jambi

Kata Kunci: Upah. Tingkat Pendidikan, Produktivitas

\section{PENDAHULUAN}

Pembangunan ekonomi tidak dapat dipisahkan dari dari peran manusia dalam mengelolanya. Kebijakan pembangunan negara mempengaruhi masyarakat (Schwarzkopf, 2014). Dimana manusia merupakan tenaga kerja, input pembangunan, juga merupakan konsumen hasil pembangunan itu sendiri. Tenaga kerja adalah aspek mendasar dalam kehidupan manusia karena mencakup dimensi sosial dan ekonomi. Tersedianya tenaga kerja dengan produktivitas yang tinggi pada setiap tahap perkembangan proyek memainkan peran penting dalam keberhasilan proyek (Nasirzadeh \& Nojedehi, 2013). Di Indonesia sendiri, dimana jumlah penduduk mencapai 220 juta orang, mempunyai sumber daya manusia yang sangat besar sekali untuk didayagunakan. Jumlah penduduk yang besar ini akan menjadi potensi atau modal bagi pembangunan ekonomi karena menyediakan tenaga kerja berlimpah sehingga mampu menciptakan nilai tambah bagi produksi nasional jika kualitasnya bagus Namun akan menjadi beban apabila kualitasnya rendah karena memiliki kemampuan dan produktivitas yang terbatas dalam menghasilkan produksi. Tingginya jumlah penduduk tetapi dengan kemampuan yang rendah rendah inilah yang menjadi masalah ketenagakerjaan di indonesia selama ini.

Membahas produktivitas tenaga kerja merupakan hal yang sangat menarik, sebab mengukur hasil-hasil tenaga kerja manusia dengan berbagai masalah yang bervariasi dalam periode tertentu. Dari beberapa literatur disebutkan bahwa banyak faktor yang dapat mempengaruhi produktivitas 
tenaga kerja. Namun dalam penelitian ini hanya fokus pada variabel upah dan pendidikan dengan mempertimbangkan pada teori upah efisiensi dan human capital. Atas dasar latar belakang tesebut maka penelitian ini bertujuan untuk menganalisis pengaruh upah dan tingkat pendidikan terhadap produktivitas upah di Provinsi Jambi.

\section{TINJAUAN TEORITIS}

\section{Produktivitas}

Menurut L. Greenberg dalam Sinungan (2008:12) mendefinisikan produktivitas sebagai perbandingan antara totalitas pengeluaran pada waktu tertentu dibagi totalitas masukan selama periode tersebut. Samuelson (1993:133) menyatakan bahwa produktivitas merupakan suatu konsep pengukuran rasio output total terhadap rata-rata input tertimbang. Sehingga berdasarkan pendapat para ahli tersebut dapat disimpulkan bahwa produktivitas adalah perbandingan antara jumlah output yang dihasilkan dengan jumlah sumber daya yang digunakan.

Dalam mengukur produktivitas, kita dapat mengartikan produktivitas total faktor produksi sebagai output per unit input total dari modal dan tenaga kerja, produktivitas tenaga kerja sebagai jumlah output per unit tenaga kerja, dan produktivitas modal sebagai output per unit modal. Produktivitas juga dapat diartikan sebagai rasio antara output terhadap input sumber daya yang dipakai. Maka

jika dalam rasio tersebut sumber daya dimasukan seluruhnya untuk menghasilkan output, maka disebut dengan produktivitas total, namun jika yang dihitung sebagai masukan hanya faktor sumber daya tertentu

saja maka disebut sebagai produktivitas parsial.

\section{Pengertian Upah}

Pengertian upah menurut UU tenaga kerja No.13 tahun 2003 adalah hak pekerja/buruh yang diterima dan dinyatakan dalam bentuk uang sebagai imbalan dari pengusaha atau pemberi kerja kepada pekerja/buruh yang ditetapkan dan dibayarkan menurut suatu perjanjian kerja, kesepakatan, atau peraturan perundang-undangan termasuk tunjangan bagi pekerja/buruh dan keluarganya atas suatu pekerjaan atau jasa yang telah atau akan dilakukan.

Upah diberikan sebagai bentuk balas jasa yang adil dan layak diberikan kepada para pekerja atas jasa-jasanya dalam mencapai tujuan organisasi. Upah dibayarkan kepada pekerja berdasarkan jam kerja, jumlah barang yang dihasilkan atau banyaknya pelayanan yang diberikan. 
Sedangkan menurut Muchdarsyah Sinungan, upah kerja adalah pencerminan pendapatan nasional dalam bentukupah uang yang diterima oleh buruh sesuai dengan jumlah dan kualitas yang dicurahkan untuk pembuatan suatu produk.

Selain pendapat di atas, ada beberapa pengertian lain tentang upah, menurut Sadono Sukirno, upah adalah pembayaran atas jasa-jasa fisik yang disediakan oleh tenaga kerja kepada para pengusaha. Sementara menurut Malayu SP. Hasibuan, upah adalah balas jasa yang dibayarkan kepada para pekerja harian dengan berpedoman atas perjanjian yang disepakati membayarnya.

Dari beberapa definisi tentang upah di atas maka dapat disimpulkan bahwa, upah merupakan imbalan yang diterima oleh pekerja dari pengusaha atas jasa yang diberikan untuk perusahaan berdasarkan lamanya jam keja dan jumlah produk yang dihasilkan, serta adanya kesepakatan antara pekerja dan pengusaha dalam menentukan besaran upah.

\section{Tingkat Pendidikan}

Menurut Taufiq Effendi (2005) pendidikan adalah "segalah usaha yang bertujuan mengembangkan sikap dan kepribadian, pengetahuan dan ketrampilan" pendidikan sebagai tulang punggung kemajuan suatu Negara, menentukan tinggi rendahnya derajat dan kedudukan bangsa. Pendidikan yang efektif melahirkan anak-anak bangsa yang cerdas, bermoral dan memiliki etos kerja dan inovasi karya yang tinggi. Seluruh Negara maju sungguh telah meletakkan kebijakan pendidikan pada posisi terdepan: mendukung mengawal dan terus memperbaiki system pendidikan bagi rakyatnya.

Menurut Andrew E. Sikula dalam Mangkunegara (2003) tingkat pendidikan adalah suatu proses jangka panjang yang menggunakan prosedur sistematis dan terorganisir, yang mana tenaga kerja manajerial mempelajari pengetahuan konseptual dan teoritis untuk tujuantujuan umum. Dengan demikian Hariandja menyatakan bahwa tingkat pendidikan seorang karyawan dapat meningkatkan daya saing perusahaan dan memperbaiki kinerja perusahaan.Menurut UU SISDIKNAS No. 20 (2003), indikator tingkat pendidikan terdiri dari jenjang pendidikan dan kesesuaian jurusan. Jenjang pendidikan adalah tahapan pendidikan yang ditetapkan berdasarkan tingkat perkembangan peserta didik, tujuan yang akan dicapai, dan kemampuan yang dikembangkan, terdiri dari:

Menurut UU RI No. 20 Tahun 2003 pasal 1, pada dasarnya jenjang pendidikan adalah tahapan pendidikan yang ditetapkan berdasarkan tingkat perkembangan peserta didik, tujuan yang akan dicapai, dan kemampuan yang dikembangkan. 
Menurut Tirtarahardja dan Sulo (2005) menjelaskan pendidikan sebagai penyiapan tenaga kerja diartikan sebagai kegiatan membimbing peserta didik sehingga memiliki bekal dasar untuk bekerja.Pembekalan dasar berupa pembentukan sikap, pengetahuan dan keterampilan kerja pada calon luaran. Kemudian khusus pada tingkat perguruan tinggi Mankiw memiliki teori khusus mengenai tenaga kerja tersebut. Perusahaan manufaktur memproduksi barang dan jasa yang kelak akan dikonsumsi dan investasi dalam modal fisik.

\section{METODE PENELITIAN}

Metode penelitian yang digunakan adalah deskriptif kuantitatif. Metode deskriptif adalah metode penelitian yang bertujuan untuk membuat gambaran mengenai situasi atau kejadian, sedangkan analisis kuantitatif adalah metode analisis yang melakukan perhitungan terhadap data-data yang bersifat pembuktian dari masalah. Sehingga metode deskriptif kuantitatif adalah metode penelitian yang memamparkan atau menjelaskan data melalui angkaangka.

\subsection{Jenis dan Sumber Data}

Data yang digunakan dalam penelitian ini adalah data sekunder, yaitu data diperoleh secara tidak langsung dari sumbernya, seperti dari website dan buku dalam angka di Badan Pusat Statistik (BPS) Provinsi Jambi, antara lain Provinsi Jambi Dalam Angka, Produk Domestik Regional Bruto (PDRB) Provinsi Jambi, jumlah tenaga kerja dan tigkat pendidikan.

\subsection{Teknik Pengumpulan Data}

Cara pengumpulan data yang digunakan dalam penelitian ini adalah studi pustaka yaitu upaya untuk memperoleh data dengan mempelajari dan menganalisis buku-buku literatur dan data-data olahan. Pengumpulan data dalam penelitian ini dimaksudkan untuk mendapatkan bahan-bahan yang relevan dan akurat. Data yang digunakan adalah data sekunder dengan menggunakan metode pengumpulan data studi secara dokumen yang berasal dari BPS Provinsi Jambi.

\subsection{Metode Analisis Data}

Alat analisis yang digunakan dalam penelitian ini dengan menggunakan model regresi linier berganda dengan model sebagai berikut:

$$
\mathrm{Y}=\beta_{0}+\beta_{1} \mathrm{X}_{1}+\beta_{2} \mathrm{X}_{2}+\mathrm{e}
$$

Keterangan :

$\mathrm{Y} \quad=$ Produktivitas Tenaga Kerja

$\mathrm{B}_{0} \quad=$ Konstanta 


$$
\begin{array}{ll}
\mathrm{B}_{1} \mathrm{~B}_{2} & =\text { Koefisien Regresi } \\
\mathrm{X}_{1} & =\text { Upah } \\
\mathrm{X}_{2} & =\text { Tingkat Pendidikan } \\
\mathrm{e} & =\text { Standart Error }
\end{array}
$$

Uji F digunakan untuk mengetahui pengaruh variabel bebas secara bersama-sama (simultan) terhadap variabel terikat. Jika $\mathrm{F}_{\text {hitung }}<\mathrm{F}_{\text {tabel }}$ 5\% maka $\mathrm{H}_{\mathrm{O}}$ diterima dan $\mathrm{H}_{1}$ menolak yang artinya variabel independen secara serentak atau bersama-sama tidak mempengaruhi variabel dependen secara signifikan. Uji T digunakan untuk mengetahui besarnya signifikan pengaruh variabel bebas terhadap variabel terikat secara individual (parsial). Dengan menganggap variabel lain bersifat konstanta. Jika thitung $>t_{\text {tabel }} 5 \%$ maka $\mathrm{H}_{\mathrm{O}}$ ditolak dan $\mathrm{H}_{1}$ diterima yang artinya salah satu variabel bebas (independen) mempengaruhi variabel terikat

\begin{tabular}{|c|c|c|c|c|c|c|}
\hline \multicolumn{7}{|c|}{ Coefficients $^{\mathrm{a}}$} \\
\hline \multirow{2}{*}{\multicolumn{2}{|c|}{ Model }} & \multicolumn{2}{|c|}{ Unstandardized Coefficients } & $\begin{array}{l}\text { Standardized } \\
\text { Coefficients }\end{array}$ & & \\
\hline & & B & Std. Error & Beta & $\mathrm{t}$ & Sig. \\
\hline \multirow[t]{3}{*}{1} & (Constant) & -34304971.569 & 32841292.660 & & -1.045 & .319 \\
\hline & Upah & 1.082 & 1.990 & 199 & .544 & .598 \\
\hline & pendidikan & 5601705.869 & 4378866.088 & .468 & 1.279 & .227 \\
\hline
\end{tabular}
(dependen) secara signifikan.

\section{HASIL PEMBAHASAN}

Dari pengolahan data maka yang telah dilakukan maka diperoleh hasil sebagai berikut:

a. Dependent Variable: Produtivitas

Dari hasil pada tabel diatas maka disusun model persamaan regresi linier berganda sebagai berikut:

$\mathrm{Y}=-34304971.569+1.082+5601705.869+\mathrm{e}$

Hasil analisis secara partial test menunjukkan bahwa upah berpengaruh positif dan tidak signifikan terhadap produktivitas tenaga kerja di Provinsi Jambi, dengan nilai koefisien sebesar 1.082. Artinya ketika terjadi kenaikan upah minimum maka akan meningkatkan produktivitas tenaga kerja. Demikian juga sebaliknya ketika terjadi penurunan upah maka produktivitas tenaga kerja mengalami penurunan. Hasil analisa ini sesuai dengan teori upah efisiensi dimana produktivitas akan mengalami peningkatan ketika terjadi kenaikan upah. Selanjutnya diperoleh hasil bahwa tingkat pendidikan juga berpengaruh positif dan tidak signifikan terhadap produktivitas tenaga kerja di Provinsi Jambi, dengan nilai kooefisien sebesar 5601705.869. 
Artinya ketika terjadi kenaikan tingkat pendidikan pada tenaga kerja maka akan meningkatkan jumlah produktivitasnya demikian juga sebaliknya ketika terjadi penurunan tingkat pendidikan maka produktivitas juga akan mengalami penurunan. Hasil penelitian ini juga sejalan dengan teori human capital yang menjelaskan bahwa peningkatan sumberdaya manusia akan meningkatkan produktivitasnya.

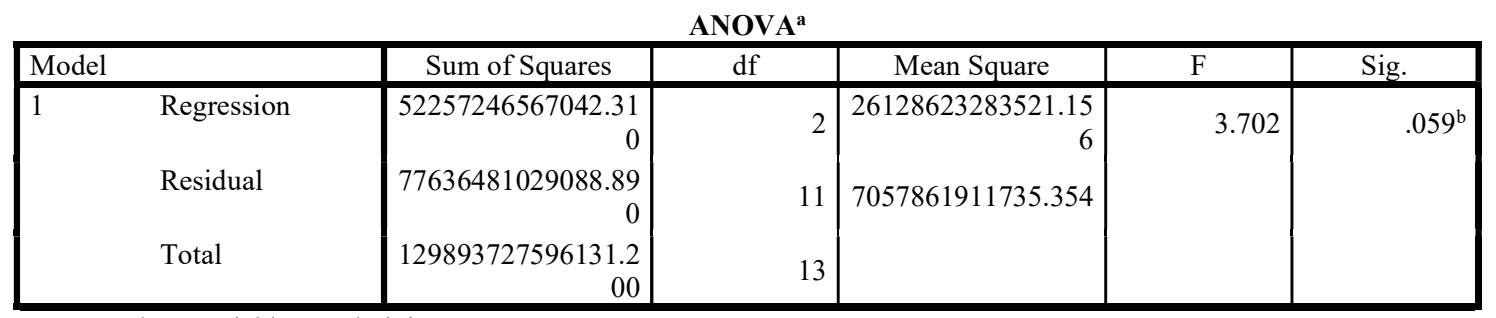

a. Dependent Variable: Produtivitas

b. Predictors: (Constant), pendidikan, Upah

Sementara berdasarkan uji $\mathrm{F}$ atau pengujian secara bersama sama (simultan) maka diperoleh hasil bahwa upah dan tingkat pendidikan berpengaruh positif terhadap produktivitas tenaga kerja tetapi tidak signifikan.

\begin{tabular}{|c|c|c|c|c|}
\hline \multicolumn{5}{|c|}{ Model Summary } \\
\hline Model & $\mathrm{R}$ & R Square & Adjusted R Square & $\begin{array}{l}\text { Std. Error of the } \\
\text { Estimate }\end{array}$ \\
\hline 1 & $.634^{\mathrm{a}}$ & .402 & .294 & 2656663.68058 \\
\hline
\end{tabular}

a. Predictors: (Constant), pendidikan, Upah

Dari hasil analisis ini juga diperoleh nilai koefisien determinasinya sebesar 0,402 atau 40,2 persen yang berarti bahwa model penelitian ini mampu di jelaskan oleh model yang ada didalam penelitian ini sebesar 40,2 persen dan sisanya di jelaskan oleh variabel lain yang tidak termasuk dalam penelitian ini.

\section{KESIMPULAN DAN SARAN}

\section{Kesimpulan}

Dari hasil penelitian ini maka dapat diperoleh kesimpulan sebagai berikut:

1. Secara parsial upah dan pendidikan berpengaruh positif dan tidak signifikan terhadap produktivitas tenaga kerja di provinsi Jambi pada tingkat signifikansi $(\alpha=0,10)$.

2. Secara simultan upah dan pendidikan tidak berpengaruh signifikan terhadap produktivitas tenaga kerja di provinsi Jambi pada tingkat signifikansi $(\alpha=0,10)$.

\section{Saran}

Beberapa saran yang dapat dilakukan diantaranya: 
1. Untuk meningkatkan produktivitas yang dilakukan melalui pendidikan dapat dilakukan dengan peningkatan skill dari tenaga kerja baik dilakukan melalui pelatihan atau perubahan arah pendidikan yang menjurus pada keahlian tenaga kerja.

2. Untuk meningkatkan produktivitas yang dilakukan melalui upah dapat dilakukan dengan cara peningkatan upah secara bertahap yang didasarkan pada tingkat produktivitas yang dihasilkan oleh tenaga kerja. Sehingga memberikan keadilan pada tenaga kerja dan perusahaan.

\section{Daftar Pustaka}

Barro, R. J. (2001). Human capital and growth. American economic review, 91(2), 12-17.

Sulaeman, A. (2014). Pengaruh upah dan pengalaman kerja terhadap produktivitas karyawan kerajinan ukiran Kabupaten Subang. Trikonomika, 13(1), 91-100.

Mahendra, A. D., \& WOYANTI, N. (2014). Analisis pengaruh pendidikan, upah, jenis kelamin, usia dan pengalaman kerja terhadap produktivitas tenaga kerja (Studi di Industri Kecil Tempe di Kota Semarang) (Doctoral dissertation, Fakultas Ekonomika dan Bisnis).

Lestari, R. W. (2011). Pengaruh Upah, Tingkat pendidikan Dan Teknologi Terhadap Produktivitas Tenaga Kerja Pada Industri Kecap Di Kecamatan Pati Kabupaten Pati (Doctoral dissertation, Universitas Negeri Semarang).

Nurfiat, N. A., \& Rustariyuni, S. D. (2018). Pengaruh upah dan teknologi terhadap produktivitas dan penyerapan tenaga kerja pada industri mebel di kota Denpasar. Piramida, 14(1), 34-48.

Yudha, O. R. P. (2013). Pengaruh Pertumbuhan Ekonomi, Upah Minimum, Tingkat Pengangguran Terbuka, dan Inflasi terhadap Kemiskinan di Indonesia Tahun 20092011 (Doctoral dissertation, Universitas Negeri Semarang).

Mankiw, N. G. (2007). Makro ekonomi edisi keenam. Jakarta: Erlangga.

Soleh, A. (2017). Masalah ketenagakerjaan dan pengangguran di Indonesia. Jurnal Ilmiah Cano Ekonomos, 6(2), 83-92.

Soleh, A. (2016). Analisis Pertumbuhan Ekonomi Indonesia. Jurnal Development, 4(2), 18-26.

Soleh, A. (2013). Analisis Struktur Ekonomi dan Ketimpangan Antar Sektor di Kabupaten Tebo Periode 2001-2010. Jurnal Development, 1(2), 30-46. 